\title{
Koellreutter como mediador entre os sul-americanos e o Internationales Musikinstitut Darmstadt entre 1949 e 1970
}

\author{
Joevan de Mattos Caitano \\ Hochschule für Musik Carl Maria von Weber Dresden | Orcid: 0000-0002-6925-5664
}

\begin{abstract}
Resumo: Hans-Joachim Koellreutter (1915-2003) ficou reconhecido como o imigrante que introduziu a técnica dos doze tons no Brasil. Dentre as diversas atividades para enriquecer a música brasileira, incluem-se também o engajamento na divulgação dos compositores brasileiros e de outros países sul americanos no Internationalen Ferienkursen für Neue Musik in Darmstadt. De 1949 até 1970, Koellreutter intercambiou cartas com os diretores do Internationales Musikinstitut Darmstadt. Assentado no material recolhido no IMD Archiv, o autor deste artigo documentar uma parte da conexão Darmstadt e América Latina pela perspectiva de Koellreutter.
\end{abstract}

Palavras-chave: Música Nova, Darmstadt, América Latina, Hans-Joachim Koellreutter, Wolfgang Steinecke.

\section{Hans-Joachim Koellreutter as mediator between South Americans and the Internationales Musikinstitut Darmstadt between 1949 and 1970}

Abstract: Hans-Joachim Koellreutter (1915-2003) became known as the immigrant who introduced the twelve-tone technique in Brazil. Among his many activities to enrich Brazilian music, he was engaged in promoting Brazilian composers and composers from other South American countries at the Internationalen Ferienkursen für Neue Musik in Darmstadt. From 1949 to 1970, Koellreutter exchanged letters with the directors of the Internationales Musikinstitut Darmstadt. Based on the material collected at IMD Archiv, the author of this article documents a part of the Darmstadt and Latin American connection from Koellreutter's perspective.

Keywords: New Music, Darmstadt, Latin America, Hans-Joachim Koellreutter, Wolfgang Steinecke.

\section{Hans-Joachim Koellreutter como mediador entre sudamericanos y el Internationales Musikinstitut Darmstadt entre 1949 y 1970}

Resúmen: Hans-Joachim Koellreutter (1915-2003) fue reconocido como el inmigrante que introdujo la técnica de los doce tonos en Brasil. Entre sus diversas actividades para enriquecer la música brasileña, también se dedicó a la promoción de compositores brasileños y de otros países sudamericanos en los Internationalen Ferienkursen für Neue Musik de Darmstadt. De 1949 a 1970, Koellreutter intercambió cartas con los directores del Internationales Musikinstitut Darmstadt. Basándose en el material recogido en el IMD Archiv, el autor de este artículo documenta una parte de la conexión entre Darmstadt y América Latina desde la perspectiva de Koellreutter.

Palabras clave: Nueva Música, Darmstadt, América Latina, Hans-Joachim Koellreutter, Wolfgang Steinecke.

ICTUS Music Journal vol. 15 n.2 


\section{Introduçáo}

O surgimento do Darmstädter Ferienkursen e as ligaçóes com músicos e instituiçóes da América Latina e de outras partes do mundo, está intimamente relacionado com a tensão entre a função institucional e a comunicação pessoal entre emigrantes exilados em outros continentes, tornando-se um problema central no processo de construçáo do internacionalismo em Darmstadt. Este processo coexistiu com a reconstrução da vida musical, significando a união do bem na Alemanha após a Segunda Guerra. Nessa época, a música clássica desenvolvida pelas filarmônicas de Berlim e Viena desempenhou o papel central, tornando-se embaixadores do mundo fazendo um trabalho político estético com atmosfera mística reconstruída em meio ao caos e escombros (TRUDU, 1992; STEPHAN, 1996; BORIO; DANUSER, 1997; CUSTODIS, 2010; NONNENMANN, 2010).

A discussão sobre "Remigrantes e políticas musicais do passado e a relação entre a ação individual e a estrutura institucional no retorno da música e dos músicos", encontra respaldo no posicionamento da musicóloga Dörte Schmidt, que relatou que até agora ainda não é possível saber o suficiente sobre a extensão do retorno dos músicos, e suas atividades para apreciar verdadeiramente o seu papel quantitativo na reconstrução da cultura musical. No entanto, aqueles que retornaram certamente se encontram em lugares políticos culturalmente centrais, especialmente na Alemanha Oriental, onde personalidades como Georg Knepler, Paul Dessau, Hanns Eisler, Ernst Hermann Meyer ou Kurt Sanderling, tornaram-se visíveis no processo de reconstrução cultural na Alemanha depois de Hitler. $\mathrm{Na}$ Alemanha Ocidental e na Áustria, aqueles que regressaram no campo da música foram geralmente integrados tacitamente, certificados no famoso caso de Theodor W. Adorno, que ocupou a posiçáo chave no mundo acadêmico ao contribuir intelectualmente para os primeiros anos dos Cursos em Darmstadt (SCHMIDT, 2013, p. 30-64).

Para situar os emigrantes como Hans-Joachim Koellreutter, Alphons Silbermann e outros no cenário de Darmstadt no final dos anos 40 e início dos anos 50, é necessário analisar o ímpeto do retorno daqueles que fugiram por diferentes razóes, gerando um mosaico de motivaçóes. $\mathrm{O}$ investimento no convite aos emigrantes para lecionar em Darmstadt, era um projeto institucional e crucial para transformar o Ferienkursen numa plataforma de comunicaçáo transfronteiriça, onde os expatriados repatriados relatavam o que estava acontecendo musicalmente em outros territórios distantes. Os primeiros anos do Darmstädter Ferienkursen coincidiram com os intensos esforços do diretor e fundador Dr. Wolfgang Steinecke para realizar obras de compositores exilados junto com Schönberg e Adorno, que se tornaram figuras centrais nos debates em torno da música nova. Outros artistas do exílio foram convidados visando preparar os estudantes para recuperar as tradições da interpretação. Naquela época, o nível estético que se discutia sobre a supremacia de "Schoenberg contra Hindemith" estava em ascensão, marcada pela confrontação da técnica de doze tons e o neoclassicismo que faziam oposição convergente. A participaçáo de HansJoachim Koellreutter no Ferienkurse em 1949, consolidou-o como palestrante representante do dodecafonismo no Brasil, que coexistiu com embate estético Schönberg vs. Hindemith nos primórdios do Kranichsteiner Ferienkurse für Neue Musik (TRUDU, 1992).

O engajamento de Hans-Joachim Koellreutter no Darmstädter Ferienkurse encontra pontos de contato em outras atividades que ele desenvolveu naquela época. Em 1948, ele trabalhou como assistente do seu antigo mentor Hermann Scherchen (1891-1966) no 
Corso Internazionale di Direzione, o $11^{\circ}$ Festival Internacional de Música Contemporânea, a Bienal de Veneza, realizada de 16 a 30 de agosto. Em Veneza, a compositora brasileira Eunice Katunda (1915-1990) que era membro da comitiva de Koellreutter, estabeleceu contato frutífero com o compositor Luigi Nono (1924-1990), permitindo o intercâmbio de informaçôes interculturais. Através de Katunda, Nono conheceu alguns ritmos brasileiros. $\mathrm{Na}$ Itália, Koellreutter deu palestras sobre música contemporânea e estética em vários centros com apoio do Círculo Cultural A. Grasmsci ligado ao Partido Comunista Italiano (KATER, 2001; IDDON, 2013; KATER, 2020).

1949 foi um ano importante para Koelreutter, pois ele participou de vários eventos importantes, entre eles, o III Congresso Internacional de Compositores de Música Progressista, realizado em Praga, o I Congresso Internacional de Compositores Dodecafónicos em Ascona, na Suíça, com a presença de John Cage e Eunice Katunda, bem como, $23^{\circ}$ Festival da Sociedade Internacional de Música Contemporânea, em Palermo. Koellreutter havia contactado Steinecke a fim de estabelecer actividades de cooperação em Darmstadt (FUGELLIE, 2018).

\section{Koellreutter no Darmstädter Ferienkurse 1949}

O primeiro contato entre Koellreutter e IMD em 24 de fevereiro de 1949. Koellreutter escreveu para Steinecke por recomendação da Sra. Maria Pinazzi em Karlsruhe. $\mathrm{Na}$ correspondência introdutória, ele expôs que estava muito interessado nos cursos de verão no Schloss Kranichstein, cuja propaganda circulava no Brasil. Ele relatou sucintamente sobre suas atividades artístico-educacionais no Brasil, e incluiu uma pequena bibliografia. Koellreutter esclareceu que seu ensino era técnico e esteticamente muito diferente de René Leibowitz (1913-1972) e expressou que queria conhecer pessoalmente o diretor em Darmstadt, pois no final de março daquele ano planejava viajar ao continente europeu para participar do Festival Internacional de Música da IGNM [Sociedade Internacional de Música Contemporânea], e do "Primeiro Congresso Internacional de música de doze tons" em Miláo. O representante brasileiro reforçou que lecionou na Itália, Áustria, Hungria, França e Suíça e sugeriu dois endereços de contacto no Rio de Janeiro e Basiléia através da pianista Lydia Haller Alimonda. ${ }^{1}$

O desejo de Koellreutter foi correspondido por Steinecke, que desde 1948, lutava para internacionalizar os cursos em Darmstadt para escutar vozes de outras culturas numa perspectiva global. Em resposta à carta de 24 de fevereiro, o diretor expressou seu desejo de manter a conexão com o Brasil e informou que os Ferienkursen foram planejados para o espaco 19 de junho até 10 de julho, quando enfocariam na situaçáo internacional da música nova, com forte ênfase no dodecafonismo em homenagem aos 75 anos de Arnold Schönberg, que havia sido convidado para o encontro. Steinecke sinalizou que Ferienkursen era uma oportunidade que permitiria Koellreutter apresentar uma palestra apresentando aos participantes sobre a técnica dos doze tons que estava sendo desenvolvida no Brasil. ${ }^{2}$

Motivado pela proposta de Steinecke para aquela ocasiáo especial, Koellreutter

$1 \quad$ Carta de Koellreutter para Steinecke. 24 de Fevereiro de 1949. IMD Archiv. O centro de apoio comunicacional de Koellreutter com o Internationales Musikinstitut Darmstadt na Europa era a sua amiga Lydia Haller-Allimonda (1917-2014). Em situaçóes de emergência, ela funcionava como ponte de ligação entre ambos os lados, pois Koellreutter era um músico itinerante, viajava com frequência e trabalhava sempre em vários lugares.

2 Carta de Steinecke a Koellreutter, 8 de março de 1949. IMD Archiv.

ICTUS Music Journal vol. 15 n.2 
delineou um projeto a ser aplicado ao público darmstadtiano para abordar história, desenvolvimento, problemas estéticos, técnicos e pedagógicos na música dodecafônica. Para isto, ele precisava de um piano à disposição no local e apresentaria gravaçôes para melhor esclarecimento durante a comunicação. $\mathrm{O}$ aspirante brasileiro detalhou o tema "Dodecafonismo" e a lista de obras premeditadas a serem apresentadas em Darmstadt. Koellreutter estava viajando pelo sul do Brasil e agradeceu a Steinecke pelas suas palavras amigáveis no dia 8 de março, notificou, que não sabia, se seria possível frequentar cursos de verão em Darmstadt naquele ano. Sua resposta dependia de outros fatores, pois ele não sabia se poderia ficar na Europa até junho ou julho. Apesar das incertezas, ele ressaltou que queria muito experienciar Darmstadt, porque o $75^{\circ}$ aniversário de Arnold Schoenberg seria, sem dúvida, uma ocasião especial. Para dar a Steinecke uma decisão final, Koellreutter expressou que provavelmente daria uma palestra melhor sobre a história, desenvolvimento, problemas estéticos, técnicos e pedagógicos da música de doze tons no Brasil. O título da palestra Música de Doze Tons no Brasil, foi entáo sugerido por Koellreutter que justificou interesse em realizar análises práticas dentro do curso de composição, para exemplicar com obras de Schoenberg, Berg, Webern e Dallapiccola. Na carta, Koellreutter enviou o repertório da nova música brasileira que foi apresentada no programa do Museu de Arte Moderna de Sáo Paulo que foi inaugurado com um concerto bem sucedido. A carta contém o seguinte repertório da música moderna brasileira: Guerra Peixe, Primeira Sinfonia (madeira lisa); Claudio Santoro, Terceira Sinfonia, Música 1944, para orquestra de cordas; Eunice Catunda, Cançôes da Morte; H-J. Koellreutter, Variaçôes 1945, Intrata para dois coros de metais. Pequeno conjunto: Guerra Peixe, Nonet para flauta, clarinete, fagote, fagote, trompete, trombone, piano, violino, viola e violoncelo, Suite para três trompetes, três trombones, tuba e tambor. Francisco Mignone, Fuga e Postludium para flauta, oboé, clarinete, trompa e fagote. Claudio Santoro, Música de Câmara 1948 para flauta, flautim, flautim, clarinete, clarinete baixo, piano, violino e violoncelo. H. J. Koellreutter, Música de Câmara 1948 para onze instrumentos solo, Cinco Nocturnos para uma parte alta e orquestra de cordas ou quarteto de cordas, Hai-kais para soprano, trompete e orquestra de cordas. (Obras folclóricas de Villa-Lobos, Francisco Mignone, Radamés Gnattali, Luiz Cosme e José Siqueira). ${ }^{3}$ Em 1949, devido a mudanças monetárias na Alemanha, Steinecke estava em uma situação difícil e precisava trabalhar como jornalista em várias cidades. Apesar da instabilidade local, ele continuou organizando os programas do Ferienkursen, embora não estivesse trabalhando como diretor do IMD (SCHLÜTER 2006, p. 33-50; CUSTODIS, 2010). Vivendo uma vida itinerante, Steinecke e Koellreutter mantiveram uma intensa colaboração bastante promissora. A carta de Koellreutter enviada de Palermo aponta que ele pretendia prorrogar a estadia na Europa com intuito de visitar os seminários e concertos em Darmstadt. Koellreutter recomendou duas obras composicionais compostas pelo jovem compositor brasileiro Guerra Peixe: "Nonett" para flauta, oboé, clarinete, fagote, trompete, trombone, piano, viola e violoncelo estreado por Hermann Scherchen, ou Kammersinfonia estreado pela Orquestra Sinfónica da BBC em Londres para os concertos do projecto Music in the young generation, idealizado por Steinecke para divulgar e promover as obras dos jovens compositores durante os cursos em Darmstadt. ${ }^{4}$

A correspondência trocada encontra ressonância histórica com a participação do emigrante alemão no Primeiro Congresso Internacional de Doze Tons realizado em Milão, em maio daquele ano, no qual participaram vários representantes de vários países como

3 Carta de Koellreutter para Steinecke. 20 de Março de 1949. IMD Archiv.

$4 \quad$ Carta de Koellreutter para Steinecke. 26 de Abril de 1949. IMD Archiv. 
Hans Erich Apostel, René Leibowitz e Georges Duhamel, Joseph Rufer, John Cage, entre outros. Juan Carlos Paz, que foi pioneiro na introdução da música dodecafônica na América do Sul em 1934, infelizmente não participou desse evento, apesar de sua ausência ter sido justificada em uma carta enviada ao compositor italiano Riccardo Malipiero em abril de 1949, quando o compositor argentino sinalizou que Koellreutter representaria sua forma de pensar, pois desde 1939 ele defendia a música doze tons no Brasil (Fugellie 2015). Na dinâmica das atividades como representante da Nova Música no Brasil, Koellreutter manteve contato com Wolfgang Steinecke expressando o desejo de participar como palestrante nos Cursos de Verão em Darmstadt. Naquela época, o número de professores internacionais aumentou anualmente, e encontrou força potencial na presença ativa de emigrantes alemães (MAUSER, 1994, p. 241-248; SCHMIDT, 2013, p. 30-56). Nessa edição de 1949, Steinecke havia planejado um encontro para homenagear o compositor Arnold Schönberg com a participaçáo de vários palestrantes convidados para falar aos doze tons em vários países, adornados com concertos no programa „Música da Nova Geração“. A participação ativa de Hans-Joachim Koellreutter em Darmstädter Ferienkursen em 1949, tratando do tema Música Dodecafônica no Brasil, convergiu com a abordagem de alguns oradores, que relataram sobre os dodecafones na França, Turquia, Estados Unidos e otros países. Uma obra do compositor brasileiro Guerra Peixe foi apresentada em Darmstadt, em um ciclo que apresentou obras de 32 compositores de 13 nacionalidades diferentes. Em sua palestra de 28 de junho de 1949, Koellreutter apresentou suas obras para piano e flauta concebidas com a técnica dodecafônica em colaboração com a pianista brasileira Lydia Alimonda, residente em Basiléia, e a cantora Gerda Fritz, residente em Karlsruhe, com a participação do Quarteto de Cordas de Darmstadt (TRUDU, 1992; BORIO; DANUSER, 1997; FUGELLIE, 2015, p. 8).

A estadia de Koellreutter na Ferienkurse 1949 estreou um momento importante nas relaçóes entre Darmstadt e América do Sul. Naquele Ferienkurse ele informou á Steinecke sobre o trabalho do musicólogo Francisco Curt Lange (1903-1997) que também era imigrante e desenvolvia um profícuo trabalho musicológico na Argentina, Uruguai e Brasil. De 1950 até 1971, Curt Lange trocou várias cartas com o IMD e enviou pelo correio diversos materiais referentes a música latinoamericana.

\section{Koellreutter no Darmstädter Ferienkurse 1951.}

A segunda participação da Koellreutter no Darmstädter Ferienkursen em 1951 está relacionada às palestras de caráter internacional, cujo objetivo era tratar da situação da música nova em diferentes países. Representando a América do Sul, ele atuou como palestrante e membro representante da seção brasileira durante o ciclo de comunicação realizado em cooperação com o XXV Festival da Sociedade Internacional de Música Contemporânea em Frankfurt (HAEFELI, 1982; KATER, 2001; FUGELLIE, 2015; FUGELLIE, 2018).

A correspondência enviada por Koellreutter a Steinecke em 17 de março de 1951, esclarece alguns detalhes, como a chegada em Gênova em 8 de junho, a confirmação início dos cursos de verão em Darmstadt, e sobre foco da palestra com ensino voltado para a dimensão prática. Koellreutter informou que dois estudantes brasileiros estavam interessados em participar dos cursos em Darmstadt e precisavam dos formulários de inscrição e do prospecto o mais rápido possível. Uma das aspirantes mencionadas era Nininha Gregori (*1925), cuja obra Grieschisch Lyrik para soprano, instrumentos de sopro e celesta foi listada 
para o Festival da Sociedade Internacional de Música Contemporânea em Frankfurt [I. G. N. M. Musikfest]. Koellreutter anexou um artigo sobre música popular brasileira, que foi publicado numa revista alemã em Buenos Aires, e sugeriu que Steinecke tentasse publicá-lo na „Mittag“, afirmando que de tempos em tempos enviaria uma peça sobre música contemporânea brasileira ou geralmente sul-americana. Koellreutter perguntou à Steinecke se ele tinha recebido as obras brasileiras para Música da jovem geração. ${ }^{5}$

Durante o curso de verão, Quatro líricas gregas (1950) para soprano, flauta, oboé, clarinete, fagote e celesta da compositora brasileira Nininha Gregori foi apresentado em Darmstadt. Paralelamente ao Darmstädter Ferienkursen, Koellreutter participou ativamente do II Congresso Internacional de Doze Tomes, realizado entre 2 e 4 de julho de 1951, que promoveu discussōes sobre Schönberg, Alban Berg, Anton Webern. Neste evento, Der Tanz one of Goldene Kalb foi performado sobre a regência de Hermann Scherchen. Naquele Ferienkursen, o engajamento de Koellreutter foi enriquecido pela contribuição de Nininha Gregori e Lavinia Viotti (1908-2008) que vieram de São Paulo, Sonia Born que residia na Suíça e Maria Lucia Mazurek que era residente em Curitiba. O tema abordado em 30 de julho de 1951 entitulou-se Música Nova na América do Sul, e Koellreutter contou com o suporte da pianista Lavinia Viotti que interpretou obras de compositores sul-americanos, com auxílio complementar de gravaçóes de algumas composiçóes. O texto original da palestra de Koellreutter está preservado no Stadtarchiv Darmstadt e IMD Archiv e foi publicado em 1997 no terceiro volume Im Zenit der Moderne editado pelos musicólogos Gianmmario Borio e Hermann Danuser (KOELLREUTTER, 1997, p. 171-177). O material aponta que Koellreutter apresentou uma visão geral da música sul-americana, dialogando com expoentes da composição musical que incluíam nomes como Alberto Ginastera, Juan Carlos Paz, Esteban Eitler, Daniel Devoto, José Ardevol, Camargo Guarnieri, Cláudio Santoro, Guerra-Peixe, Edino Krieger, Roberto Schnorrenberg, Maciel Guari, Nininha Gregori, Eduardo Maturana e Fré Focke. Estes compositores estiveram ligados aos grupos Musica Viva no Brasil, Grupo Tonus no Chile e Agupación Nueva Música em Buenos Aires (IMD Archiv; FUGELLIE, 2018).

Ao introduzir o tema Nova Música na América do Sul, Koellreutter definiu o significado do termo "nova música" em relação à América Latina, justificando que no contexto da América Latina sem tradição, a "Nova Música" só poderia significar identificação de espécies, não determinação do tempo. Recordando a distinção entre estilo antigo e estilo moderno utilizado na música europeia por volta de 1750, ao nomear Bach e Stamitz como compositores contemporâneos, Koellreutter apontou Villa-Lobos e Juan Carlos Paz que eram os representantes de dois estilos contemporâneos diametralmente opostos na América do Sul. Na América Latina em meados do século XX, a simultaneidade de dois estilos opostos significou o nascimento de uma nova cultura musical com o avanço das forças elementares e o início de sua formação mais intensiva. Para Koellreutter, toda cultura musical, antes de crescer em uma totalidade artística, alimenta-se das forças primitivas da música popular, porque a música popular como força fertilizante é uma lei intemporal na história da música. A música, como qualquer outro meio de expressão, nasce da alma de um povo, por isso as cançôes e danças folclóricas são os pilares da criação artística, carregando os germes das grandes formas musicais, e podem determinar o caráter do estilo nacional. $\mathrm{O}$ surgimento da arte do som ancorado na mente do povo, realça a sublimaçáo do pensamento e do sentimento de uma comunidade social. (IMD Archiv; KOELLREUTTER, 1997, p. 171-177; FUGELLIE, 2018).

$5 \quad$ Carta de Koellreutter para Steinecke. 17 de Março de 1951. IMD Archiv.

ISSN 1516-2737 | e-ISSN 2238-6599 
Baseada nas Cirandas de Villa-Lobos, Kollreutter argumentou que a música latino-americana nasceu das forças primordiais da nação, desde que as obras de Villa-Lobos representam a fusão de forças em uma escola nacional. Ciranda é uma música de dança, e Villa-Lobos descreve Ciranda como uma pequena peça de piano que é baseada como um cantus firmus, ancorada numa canção folclórica que tem um caráter tipicamente dançante. A série Cirandas de Villa-Lobos é uma das obras mais características da música para piano latino-americana no quesito conteúdo folclórico. Nesta composição não há obstáculos ao puro folclore, pois a obra permeia melodia, ritmo e vários sons que ressoam convergentes, como os sons das panipas indianas, que soavam na época da descoberta da América, dialogando também com os cantos monótonos de igrejas africanas, cantos pagãos orgíacos, ou melodias populares ingênuas de imigrantes europeus (KOELLREUTTER, 1997, p. 171-177; FUGELLIE, 2018).

Koellreutter havia dado palestras em Darmstadt quando os compositores da escola nacionalista na América Latina se basearam em Debussy como ponto de partida para a transformação e exploração da essência do material popular, contando com as obras de Bartók, e as obras tardias de Manuel de Falla. Outro grupo de jovens compositores latino -americanos, aproximava-se de um ideal neoclássico de expressão, graças à forte influência do Hindemith, que foi interessante e ecoou na criação de um grande número de criadores. Naquele encontro, a pianista brasileira Lavinia Viotti realizou duas das dez miniaturas do compositor brasileiro Frutuoso Viana, que são peças pequenas, fortemente reminiscentes da arte Monpou, e foram compostas exclusivamente assentadas em melodias folclóricas. Os elos com os vendedores ambulantes e com os barkers do norte do país oferecem seus produtos que são de alto conteúdo melódico e representam um tipo especial típico do rico folclore brasileiro. Ao exemplificar auditivamente estas duas obras, Koellreutter mostrou a convergência entre a harmonia de Debussy, a arte de Monpou e os impressionistas franceses, que caracterizam a maior parte da escola de compositores folclóricos latino-americanos. A peça de violino e piano do chileno Domingo Santa Cruz foi tocada e comentada por Koellreutter, que assegurou que este compositor combinava esteticamente com o grupo de compositores que se aproximavam cada vez mais de uma espécie de neoclassicismo (KOELLREUTTER, 1997, p. 172-173).

Compositores como Alberto Ginastera, Jacobo Ficher, Juan José Castro, Piá Sebastiani, José Ardevol e sua escola, assim como Camargo Guarnieri, foram citados por Koellreutter que elencou-os como potenciais criadores. De acordo com o palestrante, estes expoentes ousaram resolver um problema, que se tornou o problema da música latino-americana por excelência. Durante a palestra, a seguinte pergunta foi levantada: até que ponto o compositor será capaz de transformar o material revelado da música popular num sentido criativo? Este questionamento foi enriquecido com a performance de Lavinia Viotti que executou uma sonatina de José Ardevol. Koellreutter considerou esses compositores como representantes Música Nova no novo continente, porque eles estavam explorando uma nova área de expressão na música latino-americana, e consequentemente, estavam tentando reavaliar o material folclórico encadernado através da absorção crescente de elementos lineares-contrapuncionais. As obras composicionais desses criadores refletiram uma transição para outros reais representantes da Música Nova na América Latina, já que elementos como tom, cadência, formação de formas tradicionais, implementação imitativa e princípio, estavam cada vez mais desconectados. A justificaçáo de Koellreutter repousa no fato de que nas obras destes compositores a música popular e a dança popular não funcionam mais como uma substância nesta música, mas apenas como uma força. No entanto, 
as ligações com as fontes ainda são perceptíveis na maioria das obras destes compositores (KOELLREUTTER, 1997, p. 173).

A música nova, ou seja, a música que usa uma nova linguagem musical e procura substituir os princípios tradicionais da teoria do som por uma nova lei autónoma, estava no estágio primordial na América do Sul caracterizada pela negação do passado tonal. Juan Carlos Paz (1897-1972) voltou ao material transformado pelo expressionismo europeu, proclamando a idéia criativa como lei suprema, e única, gerando o intercomunicador do círculo do estilo, que cresceu a partir do poder elementar e marcou o nascimento da música latino-americana. Neste ambiente, as energias motor-rítmicas de uma dinâmica interior foram confrontadas por forças contrárias construtivas que cresceram numa atitude espiritual não-elementar e procuraram criar a sua própria lei estética composicional (KOELLREUTTER, 1997, p. 173-174).

A palestra de Koellreutter em Darmstadt coexistiu com a saída da escola nacionalista e seus meios de expressão relacionados, visíveis nos caminhos estéticos adotados por Juan Carlos Paz, Esteban Eitler, Daniel Devoto, Cláudio Santoro, Guerra Peixe, Edino Krieger, Roberto Ramos Schnorrenberg, Maciel Guari, Niniha Gregori e Eduardo Maturana. Em 1951, Schoenberg havia se tornado fonte e legado para a maioria dos novos compositores da América Latina, mas além dos compositores que apenas transformaram a herança de Schoenberg, haviam outros que conseguiram abrir novos caminhos na luta pela sua própria expressão e estilo de música latino-americana. Esta nova direção de som foi exemplificada pela pianista Lavinia Viotti, que tocou duas peças para piano do compositor chileno Eduardo Maturana, e do argentino Esteban Eitler. Koellreutter abordou o caminho diferente percorrido pelo jovem compositor brasileiro Roberto Ramos Schnorrenberger (*1929), pois em suas obras apareciam regiôes tonais e atonais, todavia, seu estilo ainda não limpo e eclético era muitas vezes cheio de tensão dramática e som idiossincrático. Uma obra para soprano e piano deste compositor foi apresentada em Darmstadt durante aquela palestra. (KOELLREUTTER, 1997, p. 174). Á participação de compositoras e instrumentistas brasileiras em cooperacao com Koellreutter enriquece o debate Música nova e gênero em Darmstadt na década de 1950 (REESE, 2021, p. 43-67; TUMAT, 2021, p. 17-42).

$\mathrm{O}$ antagonismo da música que sucumbe à auto-suficiência social, buscando seus próprios laços num novo sentido de comunidade na América Latina foi abordado por Koellreutter, que citou os compositores brasileiros Maciel Guari e Guerra Peixe (1914-1993) como representantes legítimos. Ambos lidaram com esses problemas no campo da música nova. Guerra Peixe foi provavelmente o mais produtivo dos compositores brasileiros em 1951, e sua inspiração veio das pessoas e da música popular. Suas origens artísticas nasceram de impulsos nacionais, e seu trabalho certamente realizou a mais significativa transformação criativa das forças elementares da música popular, que foi fundamental para o desenvolvimento da música brasileira em geral. Suas Dez Bagatelas para Piano foram executadas em Darmstadt, quando Koellreutter explicou esteticamente as características das obras de seu aluno. Guerra Peixe concebeu a obra optando pela compactação dos elementos em menor espaço e maior concentração, cuja melodia e ritmo tinham uma característica nacional nas formas de renovação (KOELLREUTTER, 1997, p. 175; ASSIS, 2015).

A participação de Koellreutter no Darmstädter Ferienkurse 1951 coexistiu com discussóes acaloradas, que estavam ocorrendo nos círculos latino-americanos e, especialmente, entre os músicos brasileiros sobre o problema da função social da música em um momento de incerteza nos princípios artísticos e que afetava a criatividade latino-americana em geral, e no campo da música nova em particular. Vários jovens talentosos abandonaram a música 
de doze tons e migraram para outras vertentes, defendendo outros ideais sob a pressão da política partidária. Koellreutter invocou o nome do compositor argentino Juan Carlos Paz, ressaltando que ele era a personalidade mais forte da Música Nova na América Latina. Juan Carlos Paz era um homem solitário Dedalus, dotado de profundo conhecimento das conexóes e problemas da música latino-americana e firme convicçâo estética, absoluta e honrosa seriedade. Não obstante, muita competência, foi condenado como um "artista alienado". Obras como Music for Piano (1950) e (1951) foram citadas na palestra em Darmstadt, exemplificando como o compositor argentino desenvolveu a linguagem sonora atonal de sua música. Infelizmente, ambas obras que são contribuições importantes para o desenvolvimento da técnica dos doze tons não foram executadas em Darmstadt, pois não chegaram por correio aéreo enviado de Buenos Aires. Para compensar a falta de duas obras que não chegaram a Darmstadt, Koellreuttter sugeriu ouvir Diez piezas en una serie de piano de doce tonos [Zehn Stück über Zwölftonserie], que era uma obra mais antiga de Juan Carlos Paz (KOELLREUTTER, 1997, p. 175-176; CORRADO, 2012).

Em 1951 Koellreutter falou em nome da América do Sul numa fase de internacionalização dos cursos de verão que se intensificou nos anos seguintes com muita propaganda difundida em todos os continentes. Naquela ocasião, Koellreutter representou os povos latino-americanos que eram muito diversos na sua composição social, e que estavam em constante transformação. Portanto, naquele momento não era possível discernir uma atitude estilística no campo musical razoavelmente uniforme da escola nacionalista que era eclética. A estética nacionalista emergiu como um movimento emancipatório que visava desenvolver uma cultura musical autônoma marcada por uma necessidade social. O nacionalismo musical era geralmente o reflexo de uma luta política e econômica pela independência ou mesmo o resultado de um impulso à individualização, que deveria ser explicado a partir das condiçôes históricas das naçóes subalternas. Koellreutter apontou para o forte desenvolvimento civilizacional, muitas vezes errático e inorgânico nos principais países latino-americanos visíveis na Argentina, no Brasil e no Chile. Nesses países, os padrões de composição europeus eram predominantes, de modo que o caminho percorrido pela escola nacionalista parecia duvidoso. Koellreutter olhou com otimismo para os confrontos entre as vertentes folclórico-nacionalistas e a música nova, acreditando que essas disputas levariam a um caminho que poderia abrir novos horizontes para a música sul-americana. Os conflitos ideológicos que provocaram a ruptura de seus alunos Claudio Santoro, Guerra-Peixe e Eunice Katunda no Grupo Música Viva, foram abordados por Koellreutter naquela histórica palestra em Darmstadt (KOELLREUTTER 1997, p. 176-177).

\section{O intercâmbio Darmstadt-Teresópolis}

O engajamento de Koellreutter Ferienkurse 1951 coexistiu com a realização do Curso Internacional de Férias Pro-Arte em Teresópolis, no Brasil, que se constituiu numa iniciativa desenvolvida pelo empresário alemão Theodor Heuberger (1899-1987) que também ocupava o cargo de diretor da Pro-Arte Sociedade de Ciências em São Paulo. A visita de Koellreutter ao Internationalen Ferienkursen für Neue Musik em Darmstadt, em 1949, possibilitou uma ampla rede de contatos e ampliou os horizontes do músico alemáo no Brasil. Animado e motivado pelo encontro em Darmstadt, ele decidiu promover um evento similar no Brasil para promover o intercâmbio entre músicos da América Latina com profissionais vindos da Europa. A fim de contribuir para o desenvolvimento do ambiente 
cultural latino-americano, Koellreutter idealizou um evento internacional que agregava potencial artístico. Graças ao apoio de Theodor Heuberger, Koellreutter inaugurou o primeiro Curso Internacional de Férias Pró-Arte em Teresópolis que tomou lugar de 3 de janeiro à 2 de fevereiro de 1950. Heuberger foi o fundador do Curso, apoiado por Maria Amélia Martins, mas a criação, concepção e materialização do projeto, foi de H. J. Koellreutter. Esse curso funcionou como laboratório de arte, e tornou-se pioneiro na fundação de outros cursos e festivais em outras cidades brasileiras como Curitiba, Ouro Preto, Brasília, Campos do Jordão, Londrina, Juiz de Fora. O Curso Internacional de Férias Pro-Arte em Teresópolis aconteceu anualmente de 1950 a 1989 , e foi realizado durante as férias de janeiro e fevereiro do verão brasileiro, tendo atraído músicos de vários países da América Latina. Além da música, o Curso de Férias cobriu as artes visuais, a literatura, o teatro, a arquitetura e a dança. Em 1952 Koellreutter afirmou que os princípios pedagógicos do Curso Internacional de Férias Pro-Arte em Teresópolis, enfatizavam a idéia da música como comunicação, intercâmbio, expressão do pensamento e sentimento humano (KATER, 1999, FERNANDES/ FIGUEREDO, 2011, p. 1497-1513, FERNANDES/FIGUEREDO, 2011, p. 626-641).

Os cursos que tiveram estrutura semelhante ao Internationalen Ferienkursen für Neue Musik in Darmstadt foram coordenados por Koellreutter entre 1950 e 1958. Os diretores artísticos da edição de 1959, foram seus alunos Roberto Schorrenberg e Heitor Alimonda (1922-2002). Nesses encontros internacionais, músicos brasileiros em parceria com Koellreutter, trabalharam como professores nas primeiras ediçóes colaborando com outros convidados, dentre eles, Geni Marcondes, Hilde Sinnek, Renato Almeida, Lais Wallach, Hans Breitinger, Damiano Cozzella e Roberto Schorrenberg. O apoio financeiro da Pro-Arte tornou possível trazer convidados internacionais, como o compositor a Ernst Krenek, residente nos EUA, o musicólogo Francisco Curt Lange, que trabalhou na Argentina. Hermann Scherchen e Paul Hindemith foram convidados para lecionar em Teresópolis em 1952 e 1953, mas não puderam corresponder o convite de Koellreutter (FUGELLIE, 2018).

A promoção desse encontro internacional no Brasil também é inseparável do projeto de cooperação desenvolvido por Hans Joachim Koellreutter e Dr. Wolfgang Steinecke em 1952 e 1953. Na carta à Koellreutter em 31 de julho de 1952, Steinecke escreveu que naquele momento ambas as partes estavam dando o primeiro passo oficial para a implementaçáo de um frutífero intercâmbio entre Teresópolis e Kranichstein, com vistas a continuidade. ${ }^{6}$ Nesse mesmo ano, Theodoro Heuberger contactou o Dr. Thierfeld no Instituto de Relaçóes Exteriores de Stuttgart, e informou que a quarta edição do Curso Internacional de Férias ProArte, em Teresópolis proporcionaria uma bolsa de estudos para o vencedor do Kranichstein Musikpreis, em Darmstadt. Ele esclareceu que a Pro Arte doou uma isenção de estudos para um vencedor do Prêmio Musikpreis Kranichstein em 1952. Como já foi referido, Gerd Kremper (Wuppertal-Barmen, Sternstr. 72) ganhou o concurso, pelo que a Pro Arte assumiu a estadia e outras despesas durante 6 semanas, mas as despesas de viagem tiveram de ser aumentadas de alguma forma. Heuberger pediu apoio ao Ministério dos Negócios Estrangeiros de Stuttgart administrado pelo Dr. Thierfeld e assegurou que o Dr. Spiecker, ministro do Governo da Renânia do Norte-Vestfália, prometeu seu apoio ao pianista Gerder Kremper, porque Wuppertal-Barmen pertence a este distrito. Heuberger gostaria de ouvir a opinião do Dr. Thierfeld sobre essa situação. ${ }^{7}$

Esta parceria bicultural continuou a ser consolidada através de uma carta da Steinecke

$6 \quad$ Carta Steinecke para Koellreutter. 31 de julho de 1952. IMD Archiv.

7 Carta da Heuberger ao Instituto de Relações Exteriores em Stuttgart. 15 de setembro de 1952. IMD

Archiv.

ISSN 1516-2737 | e-ISSN 2238-6599 
enviada ao pianista Gerd Kämper em 10 de dezembro de 1952. Steinecke estabeleceu contato com a prefeitura municipal de Wuppertall, solicitou apoio para que o jovem pianista pudesse viajar ao Brasil, e consequentemente, expôs a situaçáo do jovem pianista que foi selecionado para participar do „Curso Internacional de Verão de Música Nova em Teresópolis" com o apoio da Fundaçáo Pro Arte no Brasil e do Kranichsteiner Musikinstitut em Darmstadt. Steinecke relatou que Gerd Kämper participou do concurso deste ano para o Kranichsteiner Musikpreis ao piano e obteve sucesso especial. O Júri Internacional concedeulhe uma bolsa de estudos, concedendo-lhe o prêmio na forma de bolsa integral, garantindo a participação em Teresópolis de um aspirante a pianista alemão altamente qualificado. A Correspondência informa que os cursos de verão para música nova em Teresópolis foram agendados para janeiro e fevereiro de 1953, e o pianista Kämper decidiu viajar para o Brasil em 17 de dezembro de 1952. Mesmo assim, ele teve que resolver o problema das despesas de viagem da Alemanha para Teresópolis, cujo valor estimado era de 260 dólares. Steinecke informou que a viagem de volta do Brasil para a Alemanha seria financiado pelo próprio pianista que pretendia realizar concertos e oficinas no Brasil por vários meses para ganhar dinheiro. Steinecke já havia abordado o Instituto de Relaçóes Exteriores em Stuttgart sobre o assunto, mas havia recebido a notícia de que náo havia como apoiar a viagem de Gerd Kämper. Por esta razão, ele havia solicitado, em nome do Sr. Kämper, o apoio correspondente para a sua viagem de estudo visando novas experiências e desenvolvimento durante a sua estadia no Brasil. Steinecke salientou que Gerd Kämper era um jovem músico altamente talentoso, e sua participaçáo em cursos de veráo foi muito importante para promover o intercâmbio cultural internacional. ${ }^{8}$

Apesar de todos os problemas burocráticos que precederam a viagem do pianista alemão, Gerd Kämper chegou em Teresopólis. Koellreutter informou a Steinecke que o pianista alemão já estava entre os brasileiros e sacudiu os coraçôes dos jovens músicos participantes do evento em Teresópolis, tocando em um concerto noturno. ${ }^{9}$ Foi noticiado que no início de outubro daquele ano, Kämper pretendia participar do Concurso Backhaus Awards. Koellreutter destacou que a morte de Pedro Sinzig, meritório músico católico germano-brasileiro, possibilitou a criação de um apoio financeiro „Free Peter Sinzig“ através da fundação Pro Arte, permitindo o intercâmbio de estudantes de música alemã e brasileira a cada dois anos. No conteúdo da correspondência, Koellreutter escreveu: „Esperamos poder enviar o primeiro brasileiro a Darmstadt junto com a nossa caravana em julho". Espero que você escreva de Kranichstein para mim em breve“. Koellreutter quis publicar pelo menos algumas informaçôes durante o curso em Teresópolis, esperando também realizar sua „Sinfonia de Câmara 1949" para onze instrumentos solo em Darmstadt, que foi estreada em 1951 na emissora em Zurique. Foi pedido à Steinecke que escrevesse para Koellreuter até 20 de fevereiro no endereço da Escola Internacional de Verão, Rua Marquês de Caxias, 147 e depois de 20 de fevereiro no endereço da Escola de Música, Rua Sergipe, 271, São Paulo. „Você vem a Salzburg este ano? Antes ou depois do meu curso de Luzern quero ir a Salzburgo por alguns dias, onde poderíamos falar sobre qualquer assunto que ainda reste ". ${ }^{10}$

O contexto desse intercâmbio implementado por Koellreutter e Steinecke em 1952 e 1953 encontra ressonância na fundação da „Escola Livre de Música de São Paulo Pro-Arte“ e da "Escola de Música de Piracicaba" como importantes centros de ensino de música fora

8 Carta de Wolfgang Steinecke para Gerd Kämper. 10 de dezembro de 1952. Veja também: O certificado para Gerd Kämper sobre o Prémio de Música Kranichstein. IMD Archiv.

9 Carta do Koellreutter para o Steinecke. 13 de Janeiro de 1953. IMD Archiv.

10 Carta do Koellreutter para o Steinecke. 13 de Janeiro de 1953. IMD Archiv.

ICTUS Music Journal vol. 15 n.2 
dos padrões conservadores. Estas instituições tornaram-se referências para a inauguração dos Seminários Internacionais de Música em Salvador-Bahia, em 1954, e do Instituto de Música da Universidade Federal da Bahia (UFBA) fundado por Koellreutter (PARASKEVAÍDIS; KOELLREUTTER, 1984; RISÉRIO, 1995; NOGUEIRA, 2012). No engajamento nesta escola com propostas inovadoras, Koellreutter continuou a se conectar com Steinecke em Darmstadt relatando as atividades como crítico musical de um jornal brasileiro em colaboração com Ernst Mahle (*1929), que que estava trabalhando em São Paulo e também eestabeleceu contatos com Steinecke em Darmstadt. ${ }^{11}$ Steinecke escreveu a Mahler e informou que poderia enviar os folhetos em 14 dias e as informaçôes mais detalhadas sobre o curso de verão do Kranichsteiner. De qualquer forma, a maioria dos cursos eram multilingues, pelo que náo houve dificuldades para os participantes que tiveram a oportunidade de receber bolsas de estudo para participar no evento em Darmstadt. Steinecke estava esperando um grupo maior de músicos brasileiros em Darmstadt, e relatou que as indicaçóes ao Prêmio Kranichstein de Música poderiam ser encontradas naquele ano nos seguintes departamentos: piano, violino, flauta e música de câmara. Ele parabenizou Koellreutter pelo seu Frei Pedro Sinzig, que soou muito bem, pois essa iniciativa surgiu como mais uma possibilidade de continuar o intercâmbio entre Teresópolis e Kranichstein. Steinecke lembrou que Gerd Kämper escreveu-lhe de Teresópolis e ficou muito entusiasmado com o ambiente no Brasil. Seu testemunho criou uma boa impressão do trabalho de Koellreutter. Steinecke ficou muito feliz, mas lamentou a impossibilidade de apresentar a Sinfonia de Câmara de Koellreutter durante a Darmstädter Ferienkurse em 1953, porque a Orquestra de Teatro do Estado náo pôde comparecer ao evento. Steinecke estava limitado estruturalmente, mas esperava ter mais oportunidades a este respeito em 1954 e salientou que gostaria muito de falar pessoalmente com Koellreutter sobre o desenvolvimento e a construção da sua cooperaçáo bicultural. ${ }^{12}$

Em 1953 foi criado o prêmio "Frei Pedro Sinzig" em Teresópolis, que financiou bianualmente a viagem de um músico alemáo ao Brasil e de um músico brasileiro à Alemanha, que visava fortalecer o intercâmbio entre o Internationales Musikinstitut Darmstadt e o Pro-Arte. O projeto foi posto em prática e Wolfgang Steinecke ofereceu $50 \%$ de bolsas de estudo para participantes brasileiros no Darmstädter Ferienkursen, pois estava entusiasmado com o projeto que visava organizar uma caravana brasileira para Darmstadt. No entanto, o projeto tornou-se inviável devido ao aumento repentino do dólar, que permitiu apenas a visita dos alunos do Koellreutter, Ernst Mahle, Gert Simon e Sonia Born, que puderam viajar para o Ferienkursen. ${ }^{13}$ Além de Ernst Mahle e Gerd Simon, Koellreutter citou o nome da ex-aluna Barbara Brieger, porém, mais tarde, em carta datada de 18 de junho de 1953, Koellreutter informou a Steinecke que Barbara Brieger não viajaria para Darmstadt. ${ }^{14}$ Nesse mesmo ano, o pianista alemão Hans Alexander Kaul (1926-1969), que tinha participado como intérprete em Darmstadt, recebeu uma bolsa de estudos para participar dos Cursos em Teresópolis, em agradecimento a Steinecke, que disponibilizou três bolsas de estudos para músicos sul-americanos (FUGELLIE, 2015, p. 13).

11 Mahle e Steinecke. IMD Archiv.

12 Carta de Steinecke para Koellreutter. 3 de Março de 1953. IMD Archiv

13 Carta do Koellreutter para o Steinecke. 16 de Maio de 1953. IMD Archiv. Sobre a confirmaçăo de Ernst Mahle junto ao IMD, ver Carta de Mahle em 21 de junho de 1953. IMD Archiv. "Com agradecimento, confirmamos o recebimento de sua inscrição para os cursos de veráo e informamos que o inscrevemos para os cursos de Messiaen e Kurt Redel como participantes, assim como para o alojamento e as refeiçôes no seminário Marienhöhe. Como a sua inscrição foi feita a partir de Stuttgart, eu também envio uma cópia desta confirmaçẫo para o endereço de Stuttgart". [Traduzido pelo autor]

14 Carta do Koellreutter para o Steinecke. 18 de Junho de 1953. IMD Archiv.

ISSN 1516-2737 | e-ISSN 2238-6599 


\section{Koellreutter e a ligaçáo Bahia-Darmstadt}

Koellreutter fundou os Seminários Internacionais de Música de Salvador em 1954, na Universidade Federal da Bahia (UFBA), graças ao apoio do Reitor Edgard Santos (1894-1962), que em 1946 fundou a UFBA para colocar a Bahia em um ambiente internacional, num contexto de intensa agitação cultural. Estes seminários institucionalmente ligados à UFBA em colaboração com a Escola Livre de Música em São Paulo, foram baseados na mesma estrutura do Curso Internacional de Férias Pro-Arte. Koellreutter realizou anualmente os Seminários Internacionais de Música em Salvador de 1954 a 1962, mais tarde rebatizados como Seminários Livres de Música (NOGUEIRA/ROSA, 2011, p. 145-156, NOGUEIRA, 2012).

O discurso de Koellreutter no encerramento do primeiro evento em 1954 ressoou com os ideais do visionário reitor Edgard Santos, e tornou-se um pontapé inicial para a implementaçáo do curso superior de música, teatro, dança filiada, no Museu de Arte Moderna e Centro de Estudos Afro-Orientais ligado à Universidade. O engajamento de Koellreutter em parceria com Edgard Santos, tornou possível a contribuição de um grande número de professores europeus, que lecionaram na Bahia (KATER, 1997, p. 33, NOGUEIRA, 2011, p. 351-380). ${ }^{15}$

A inauguração dos Seminários Internacionais de Música transformou a Reitoria da Universidade da Bahia em um novo centro de comunicação na década de 1950 com o Internationales Musikinstitut Darmstadt através de correspondências intercambiadas por Hans-Joachim Koellreutter, pelo maestro Ernst Huber-Contwig - diretor do Musica Nova Ensemble - durante os anos 1960, e pelo compositor e professor Ernst Widmer (1927-1990) durante os anos 1970. Estes representantes informaram ao IMD sobre o progresso dos novos cursos de música, os resultados obtidos, e os jovens talentosos compositores brasileiros. ${ }^{16}$

A emigração de Hans-Joachim Koellreutter para trabalhar na Índia de 1965 a 1969, e mais tarde no Japão de 1970 a 1974, deixou uma lacuna na Bahia. Ernst Huber-Contwig e Ernst Widmer ocuparam posiçóes-chave no cenário musical de vanguarda na Bahia. As relaçóes entre a Reitoria da Universidade da Bahia e o Internationales Musikinstitut Darmstadt começaram com as cartas trocadas por Koellreutter e Wolfgang Steinecke em meados dos anos 50, e continuaram com Ernst Huber-Contwig, que escreveu para Ernst Thomas informando sobre o que estava acontecendo no âmbito da música contemporânea em Salvador. A comunicaçáo de 1966 a 1976 é certificada em mais de 30 ítens preservados no IMD Archiv (LANGE, 1958, p. 659-663, GOJOWY, 2008, p. 248-251). O fluxo de

15 O jovem compositor Carlos Vinholes foi assistente de Koellreutter na Escola Livre de Música de São Paulo, inaugurada em 1952. Koellreutter visitou Salvador em 1953 e deu três palestras sobre música moderna na Universidade Federal da Bahia e o reitor Edgard Santos lhe propôs a criação de seminários de música contemporânea com o apoio de professores do Brasil e do exterior. Os cursos na Bahia foram semelhantes aos cursos em Teresópolis, pois ambos foram concebidos utilizando o mesmo padrão com dois meses de duraçáo, visando desenvolver novas idéias de composição, introduzir análises para conhecer os princípios estéticos da música de vanguarda, criar possibilidades para um amplo estudo da música. Segundo Carlos Vinholes, na época a Casa Vitale importava partituras de obras de compositores europeus. Ver "Koellreutter: Seminário Internacional da Bahia-1954 (Vinholes, por Lilia Rosa)". https://www.youtube.com/watch?v=ohKhWy6b17M Acessado em 20 de setembro de 2021.

16 No IMD Archiv há várias cartas trocadas em diferentes momentos entre estes 3 emigrantes na Bahia e os diretores do IMD. Antes de se mudar para Salvador na Bahia-Brasil, Ernst Huber-Contwig trabalhou musicalmente no Chile. Durante a pesquisa de campo no IMD Archiv, o autor deste artigo encontrou algumas correspondência trocadas entre a Contwig e IMD enviadas pelo Instituto Goethe em Santiago, Chile. 
correspondências difundiu os Darmstädter Ferienkursen em vários países da América do Sul, e possibilitou a troca de partituras e gravaçôes de obras composicionais produzidas na Alemanha Ocidental e Bahia. Este fluxo dinâmico, tornou conhecido em Darmstadt os chamados „compositores da Bahia“, cujo nomes foram apresentados fotograficamente ao IMD. ${ }^{17}$

Além de Ernst Huber-Contwig, o emigrante suíço Ernst Widmer (1927-1990) foi outro interlocutor da música de vanguarda na Bahia. Foi professor de composição na Universidade Federal da Babia de 1963 a 1987 (NOGUEIRA, 1997, COSTA LIMA, 1999, OLIVEIRA, 2010, GOLDENBAUM, 2012). O apoio de Ernst Widmer ao grupo jovem vanguardista de Salvador coexistiu com os contatos estabelecidos com o IMD em 1970, quando ele escreveu para Ernst Thomas representando a Escola de Música e Artes Cênicas da Universidade Federal da Bahia. Na carta datada de 13 de novembro de 1970, o emigrante suíço escreveu ao diretor Ernst Thomas afirmando que estava em Darmstadt em 1953, e nesse evento participou dos seminários sobre Schulmusik, mas havia perdido seu certificado de participação. Widmer tinha pedido o envio de um novo certificado. A resposta de Ernst Thomas em 24 de novembro de 1970 aponta que o certificado solicitado não poderia ser enviado porque o nome de Ernst Widmer não foi encontrado na lista de participantes em 1953 e, além disso, nenhum curso de música escolar foi organizado pelo IMD. Ernst Thomas sugeriu que ele entrasse em contato com o INMM Institut für Neue Musik und Musikerziehung (Instituto de Música Nova e Educação Musical de Darmstadt), porque talvez eles pudessem ajudar em alguma coisa. ${ }^{18}$

\section{Koellreutter e os contatos com Ernst Thomas no IMD (1961-1970)}

O caos instalado no território brasileiro e a renúncia de Edgard Santos à reitoria da Universidade da Bahia em 1961, enfraqueceram a promoção de projetos interdisciplinares e afetaram a vida acadêmica. Este caos culminou no abandono de Koellreutter da coordenação dos Seminários Musicais ligados à UFBA em 1963, antes da adesão do governador do Estado da Bahia ao golpe militar em 1964. Desamparado e sem esperança diante desse contexto político conturbado, Koellreutter decidiu mudar-se para Berlim com uma doação da Fundação Ford, seguido de um convite para trabalhar no departamento de programas internacionais do Instituto Goethe em Munique, que o indicou para trabalhar no Oriente. Na Índia ele trabalhou de 1966 a 1969. (KATER, 2001, p. 201-202). A estética oriental absorvida durante esse período na Índia está presente em algumas obras como India Report, Sunyata, Advaita (KATER, 1997, p. 3-8 e 34-36). A experiência de Koellreutter na Índia encorajou-o a escrever um livro publicado em inglês após a sua estadia na Índia, abordando os aspectos fundamentais da estética da música clássica, os principais instrumentos e o trabalho de alguns músicos indianos importantes (KOELLREUTTER, 1960; KOELLREUTTER, 1987; KOELLREUTTER, 1989; MENDES, 2002, p. 24-29).

As relações entre Koellreutter e Darmstadt na liderança Steinecke foram marcadas pela troca de cartas no espaço entre 1949 e 1959. Em 31 de março de 1964, a Ditadura

$17 \quad$ No IMD Archiv há uma foto datada de 11 de maio de 1970. Segundo o compositor baiano Paulo Costa Lima, esta foto foi feita na Escola de Música da Universidade da Bahia. Grupo de compositores de Salvador da Bahia, Brasil. Cardoso, Lindembergue Rocha; Cerqueira, Fernando Barbosa de; Widmer, Ernst; Gomes, Milton; Oliveira, Jamary; Herrera, Rufo. IMD-B3002695.

18 Carta de Widmer a Thomas, a 13 de Novembro de 1970. IMD Archiv. 
Militar no Brasil emergiu e Koellreutter migrou para Berlim. Em seguida, ele trabalhou como diretor do Instituto Goethe em Munique, e estabeleceu contatos com vários compositores, entre eles o compositor Günther Becker (1924-2007), que estava vivendo em Atenas.

Steinecke faleceu em 1961 e Koellreutter contactou Ernst Thomas em 1964, solicitando bolsas de estudo para os jovens compositores argentinos Carlos Roqué Alsina (*1949) e Enrique Belloc (1936-2020) que aspiravam experienciar Darmstadt. Ambos estavam estudando em Berlim e receberam apoio intermediário de Koellreutter. Segundo o Koellreutter, Alsina não tinha os recursos financeiros para viajar a Darmstadt. Tanto Belloc como Alcina estavam interessados no curso de Henri Pousseur (1929-2009) sobre "Requisitos Teóricos para Música Eletrônica" e no Studio for Electronic Music em Munique. Koellreutter informou que também queria participar dos cursos de verão entre 20 e 24 de julho em Darmstadt, mas o IMD Archiv não fornece nenhuma prova que confirme a visita oficial de Koellreutter naquele veráo. ${ }^{19}$ Ernst Thomas respondeu Koellreutter assegurando que o pedido de bolsa de estudos foi concedido a Carlos Roque Alsina. No entanto, essa bolsa inicialmente só se aplicava aos cursos em Darmstadt, porque as bolsas de estudo para o suplemento de estúdio de Munique ainda não tinham sido decididas na Baviera. Ernst Thomas enviou os documentos apropriados aos dois compositores argentinos para se inscreverem no Ferienkurse 1964 e expressou sua satisfação pelo fato de Koellreutter pretender voltar a Darmstadt naquele ano porque ele poderia contribuir criticamente durante o congresso de notação que abriria portas para discussóes esperançosamente animadas. ${ }^{20}$ Koellreutter agradeceu a bolsa de estudos concedido à Alsina e reafirmou que gostaria muito de contribuir no Congresso de Notaçáo Musical, mas estava com medo de chegar atrasado a Darmstadt. Devido a vários compromissos agendados, ele achou difícil chegar na cidade antes de 22 de junho de 1964. ${ }^{21}$

Carlos Roqué Alsina viajou a Berlim e se apresentou em um concurso musical que Hans-Joachim Koellreutter anunciou em uma revista cultural em Buenos Aires. „Artistas em residência“" - com recursos da Fundação Ford - foi orientado pelo DAAD e liderado por Peter Nestler $\left({ }^{*} 1937\right)$. Através de Peter Nestler, Carlos Alsina experimentou todas modalidades, enviando notas, biografias. Mais tarde, Carlos Alsina percebeu que este programa cultural com personalidades conhecidas convidou jovens artistas internacionais que poderiam ou não ter uma recomendação para trabalhar. $\mathrm{O}$ advento desse concurso permitiu a Carlos Alsina conhecer Hans-Joachim Koellreutter em Berlim, uma pessoa de grande cultura e inteligência. Seu relacionamento foi muito cordial, mas esteticamente difícil para criar uma troca positiva. Alsina já tinha uma formação sólida graças estudos com um formidável maestro professor alemão que morava em Buenos Aires. Finalmente, em Berlim, Alsina trabalhou sozinho e mais tarde contactou Luciano Berio (1925-2003), que também foi convidado

19 Carta de Koellreutter para Thomas. 28 de abril de 1964. IMD Archiv. O IMD conserva mais de 82 ítens (82 Datensätze) que documentam a participação de Carlos Roque Alsina no Darmstädter Ferienkursen. O material arquivado incluem várias cartas trocadas com o Internationales Musikinstitut Darmstadt, fotos, gravaçóes de som e palestras. A presença intensa e pró-activa de Carlos Alcina em Darmstadt no espaço 19641976 foi provavelmente possível graças aos esforços de Hans-Joachim Koellreutter em 1964 que participou como facilitador. Sobre Enrique Belloc ver Latin American Classical Composers: Um Dicionário Biográfico. Editado por Martha Furman Schleifer (Editora), Gary Galván (Editor), Rowman \& Littlefield Publishers; Terceira edição: 2016, p. 70.

20 Carta de Thomas para Koellreutter. 14 de Maio de 1964. IMD Archiv.

21 Carta de Koellreutter paraThomas. 21 de Maio de 1964. IMD Archiv. Ver também Inscrição de Enrique José Onaria Belloc para os cursos de verão. Inscrição de Carlos M. Roqué Alsina para os cursos de verão. IMD Archiv.

ICTUS Music Journal vol. 15 n.2 
pela Fundação Ford. Alsina já conhecia e apreciava muito a música deste compositor e seu „universo“ girava em torno de Berio, Maderna, Stockhausen, Boulez e Ligeti. Alsina mostrou suas obras composicionais para Berio e realmente uma grande amizade foi criada entre ambos. Berio deu alguns conselhos musicais e abriu portas para encontrar concertos, pois Alcina era um pianista especializado em música contemporânea e aconselhou o compositor argentino frequentar cursos de verão em Darmstadt e conversar com Bruno Maderna (1920-1973). Alsina disse que não se lembrava mais da bolsa de estudos do IMD, mas decidiu viajar para Darmstadt com ou sem bolsa de estudos. Segundo Alsina, Darmstadt lhe pareceu um „deprestígio“ intelectual e venerável, no qual coexistiam altas personalidades e tolos pretensiosos. Houve palestras extraordinárias, mas num incompreensível Hochdeutsch [alemão padrão], mesmo para os alemães. Os cooncertos foram muito interessantes com excelentes intérpretes. Os programas nem sempre foram excelentes. Naquele evento em Darmstadt Alsina aproximou-se de Maderna e mostrou algumas de suas obras composicionais. Os cursos em Darmstadt e o encontro com Maderna foram decisivos para a carreira do pianista e compositor sul americano. Maderna apreciou a música de Alsina e pediu-lhe para terminar a obra que estava a compor em Berlim (Funktionen Op. 14) e que foi estreada em Darmstadt em 1965 e mais tarde em Berlim sob a regência de Maderna. A création mondiale, por outro lado, foi realizada pouco antes, em Paris, num concerto do Domaine Musical (GALPÉRINE, 2011). ${ }^{22}$

\section{Koellreutter e o projeto Darmstadt no Japáo em 1970}

Koellreutter foi inaugurado como diretor do Instituto Cultural Alemão (Instituto Goethe) em Tóquio, em 25 de dezembro daquele ano, e defendeu a integração, o intercâmbio e a reconciliação em meio à diversidade de interesses conflitantes através do discurso intercultural. Fragmentos extraídos do discurso inaugural, destacam que Koellreutter enfatizou que o instituto cultural alemáo deveria se abster do excesso de propagandas e, ao invés disso, colocar em primeiro plano a cooperação e o intercâmbio bilateral. Koellreutter foi empossado no cargo e em seguida foi chamado para trabalhar em outro projeto em 1970 visando implementar o Departamento de Música da Universidade de Campinas (UNICAMP). Entretanto, Benito Juarez, seu ex-aluno em São Paulo, coordenou esse projeto, já que Koellreutter precisava se concentrar nas atividades trabalhando como diretor no Japão (KOELLREUTTER; TANAKA, 1983, p. 19-24; KATER, 2001).

Durante sua liderança no Goethe Institute em 1970, Koellreutter esboçou um projeto de intercâmbio Darmstadt-Japão, que foi encaminhado ao Internationales Musikinstitut Darmstadt, liderado por Ernst Thomas desde 1962. Na carta ao diretor do IMD, Koellreutter escreveu que ele pediu a Aloys Kontarsky, Sr. Drecheler, Egon Kraus e sua esposa, que estavam em Darmstadt para informá-lo sobre as intençóes. Koellreutter justificou que ele náo tinha contactado o IMD antes, porque até algumas semanas antes, ainda não estava claro se ele teria apoio financeiro para colocar alguns planos em prática. Koellreutter recebeu um convite inesperado de duas universidades brasileiras, para as quais deu palestras em julho e agosto. Por sugestão de seus colegas japoneses, no início de agosto de cada ano, Koellreutter planejou um curso de verão de dez dias com foco em composição e interpretação de música nova e gostaria de realizar esses cursos de verão com o subtítulo „Darmstadt no Japão“, em estreita colaboraçáo com Ernst Thomas. Isto significava que Koellreutter gostaria de ter

22 Email enviado por Carlos Roqué Alsina ao autor deste artigo em 4 de fevereiro de 2019.

ISSN 1516-2737 | e-ISSN 2238-6599 
fitas gravadas todos os anos em Darmstadt com as obras de compositores japoneses, que estrearam em concertos durante o Darmstädter Ferienkursen em anos anteriores. Koellreutter pretendia convidar todos os anos um ou dois oradores pertencentes ao „Círculo de Darmstadt", tendo em vista uma cooperaçáo. Para Koellreutter, este projeto bicultural seria politicamente interessante para o IMD e para os músicos/instituiçóes japonesas. Koellreutter esboçou a possibilidade de desenvolver seminário em Karuizawa, talvez o resort de verão mais popular da regiáo, localizado a duas horas de Tóquio nas montanhas, que lhes daria todo o seu espaço por 10 dias em agosto, e anexou um folheto à carta enviada ao IMD, que seria realizada pela primeira vez de 6 a 16 de agosto de 1971. Como orador convidado, Koellreutter convidou Aloys Kontarsky, que tinha a perspectiva de viajar ao Japão, e declarou que ficaria feliz se Ernst Thomas pudesse patrocinar os Cursos Internacionais de Verão em Karuizawa. No final da correspondência, Koellreutter expressou que ficaria grato se Ernst Thomas ocasionalmente lhe escrevesse algumas linhas sobre o assunto, talvez dando sugestóes que seriam de interesse para a implicação desse plano. Ele pediu desculpas pela carta tardia, mas estava convencido de que havia possibilidades materiais para o curso no Japão. ${ }^{23}$

Durante sua estadia como diretor artístico do Instituto Goethe em Tóquio de 1970 a 1974, Koellreutter organizou eventos promovendo concertos que misturaram filosofia, física, política e música nova com obras de autores/compositores/performadores japoneses e alemães em cooperação com sua esposa Margarita Schack, soprano especializada em música moderna. Ele apoiou eventos biculturais como o Japanisch-Deutsches Festival für Neue Musik e colaborou diretamente com compositores e intérpretes japoneses. Yori-Aki Matsudaira afirmou ter composto algumas obras para piano e soprano dedicadas a Margaret Schack, soprano e esposa de Koellreutter durante 1970 e $1974 .{ }^{24}$

Do ponto de vista estético composicional, a experiência de Koellreutter vivendo no Japão, fecundou seu potencial criativo que se fundiu em sua produção ao acrescentar elementos da cultura asiática. No Japão, Koellreutter compôs obras para Shakuhachi e Orquestra, e incorporou elementos da cultura japonesa para compor com estilo e assinatura (PIMENTA, 2010; WOLLF, 2016).

Em 1975, Koellreutter retornou ao Brasil após 13 anos no exterior e assumiu a liderança do Instituto Goethe no Rio de Janeiro, quando deu suporte institucional ao compositor Maki Ishii (1936-2003) que visitou o Brasil em 1978 com seu „Tokk - Ensemble Tokyo" quando realizou concertos em Salvador, Rio de Janeiro e São Paulo. Obras de alguns compositores japoneses foram apresentadas nessa época. ${ }^{25}$

\section{Conclusão}

A experiência artística de Koellreutter na Alemanha, Brasil, Índia e Japão fez dele um músico transnacional, que experimentou caminhos híbridos formados por uma vida de história entrelaçada. No século XXI, as interdependências se acentuam em um mundo globalizado. Koellreutter representou o potencial de convergência entre diversas culturas e

$23 \quad$ Carta do Koellreutter ao Thomas. 7 de Setembro de 1970. IMD Archiv.

24 Yori-Aki Matsudaira em entrevista ao autor deste artigo em Junho de 2017 na sua casa em NerimaTokyo.

25 Maki Ishii Musical Archive (Maki Ishii Memorial) em Berlim. Segundo o arquivista Kei Ishii filho do compositor, o arquivo conserva os programas dos concertos liderados por Maki Ishii realizados no Brasil em 1978, além de um diário escrito por seu pai sobre a turnê na América do Sul. 
foi muito importante na história da música brasileira no século 20 . Seu legado ainda está aberto a várias pesquisas no campo da música e da interculturalidade, pois há uma rica reserva de materiais na Fundação Koellreutter da Universidade de São João Del-Rei, no Brasil.

A pluralidade de documentos preservados no IMD Archiv ligando Koellreutter e Darmstadt, aponta uma lacuna entre 1965 e 1969, durante a estadia de Koellreutter na Índia como músico e diretor do Goethe Institute em Nova Delhi. De 1970 a 1975 Koellreutter ocupou o cargo de diretor no Goethe Institute em Tóquio, portanto as ligaçóes Koellreutter e Darmstadt entre 1970 e 1974 ainda têm lacunas, pois o IMD preserva apenas uma carta.

Hans-Joachim Koellreutter foi um transformador de mentalidades, porque procurou sensibilizar os alunos para se tornarem músicos e professores, suscitando questôes de ideias e abertura ao mundo através de novas formas de ouvir música. Friedrich Hommel (1929-2011) trabalhou como diretor geral do Darmstädter Ferienkursen de 1981 a 1994. Koellreutter entrou em contato com Hommel e seu assistente Wilhelm Schlüter? O IMD Archiv não informa sobre as comunicações de Koellreutter e Hommel. Será que Koellreutter perdeu o interesse pela música nova em Darmstadt? Que impacto Darmstadt teve sobre os brasileiros naquela época? Sua morte em 2005 representou a despedida de uma celebridade cuja vida foi marcada por um intenso engajamento para expandir a música de vanguarda na América Latina, Índia e Japão. 


\section{Referências}

BRITO, Teca Alencar de. Hans-Joachim Koellreutter. Idéias de Mundo, de Música, de Educação. São Paulo: EDUSP, 2015.

BORIO, Gianmario e Hermann DANUSER (editores.). Im Zenit der Moderne: die Internationalen Ferienkurse für Neue Musik Darmstadt 1946-1966: Geschichte und Dokumentation. Freiburg im Breisgau: Rombach, 1997.

CUSTODIS, Michael. Traditionen-Koalitionen-Visionen, Wolfgang Steinecke und die Internationalen Ferienkurse em Darmstadt. Saarbrücken: PFAU, 2010.

ASSIS, Ana Cláudia de. Os doze sons e a cor nacional: conciliaçóes estéticas e culturais na produçáo musical de César Guerra-Peixe (1944 - 1954). São Paulo. Annablume, 2015.

CORRADO, Omar. Vanguardias al Sur: la música de Juan Carlos Paz. Buenos Aires: Universidad Nacional de Quilmes, 2012.

COSTA LIMA, Paulo. Ernst Widmer e o Ensino de Composiçáo Musical na Bahia. Salvador: Fazcultura/Copene, 1999.

FERNANDES, José Nunes e Denise FIGUEREDO. "O ensino de música em cursos e festivais de férias: o caso do Curso Internacional de Férias Pro Arte de Teresópolis (1950 a 1989)? sua origem, seu pioneirismo e seu nível". Em XIX Congresso Anual da ABEM, 2011, Goiânia. Anais do XIX Congresso Anual da ABEM. Goiânia: ABEM, v. 1, 2011, p. 1497-1513.

FERNANDES, José Nunes e Denise FIGUEREDO. "Curso Internacional de Férias Pro Arte de Teresópolis (1950 a 1989): seu processo educativo-musical”. Em XIX Congresso Anual da ABEM, 2010, Goiânia. Anais do XIX Congresso Anual da ABEM. Goiânia: ABEM, v. 1; 2011, p. 626-641.

FUGELLIE, Daniela. Hans-Joachim Koellreutter y la música sudamericana en los Cursos Internacionales de Verano de Darmstadt (1949-1951). Manuscrito/aula apresentado durante o Simpósio de Musicologia organizado pela Escola de Música da Universidade Federal do Rio de Janeiro em cooperação com a Universidade de Artes de Berlim. Evento musicológico realizado na UFRJ-Rio de Janeiro, 2015.

FUGELLIE, Daniela. Musiker unserer unserer Zeit“". Internationale Avantgarde, Migration und Wiener Schule em Südamerika. Munique: texto de edição + kritik, 2018.

FUGELLIE, Daniela. Nueva música, música viva, tonus e os caminhos da dodecafonia na América do Sul (1930-1960). Revista Música Hodie, 18(2), 2018, p. 168-182. https://doi.org/10.5216/mh.v18i2.53398

GALPÉRINE, Alexis. Carlos Roqué Alsina - entretiens, témoignages, documentos. Sampzon: Delatour France, 2011. 
GALVÁN, Gary e Furman SCHLEIFER (editores.). Compositores clássicos da América Latina: Um Dicionário Biográfico. Lanham: Rowman \& Littlefield Publishers; Terceira edição, 2016.

GOJOWY, Detlef. Musikstunden: Beobachtungen, Verfolgungen und Chroniken neuer Tonkunst. Cologne: dohr, 2008,

GOLDENBAUM, Jean Marco Arendt. Neue Noten unter einem neuen Himmel: Die in Brasilien eingewanderten deutschsprachsprachigen Komponisten und deren Einfluss auf die brasilianische Musik. Augsburg: PhD., Diss, 2012.

HAEFELI, Anton. Die Internationale Gesellschaft für Neue Musik (IGNM). Ihre Geschichte von 1922 bis zur Gegenwart. Zurique: Atlantis Musikbuch, 1982,

KATER, Carlos. Catálogo de obras de H. J. Koellreutter. Belo Horizonte: FAPEMIG, 1997.

KATER, Carlos. Música Viva e H. J. Koellreutter: movimentos em direçáo à modernidade. Musa Editora, Atravez, 2001, p. 188-190.

KATER, Carlos. Eunice Katunda: musicista brasileira. Belo Horizonte: Carlos Kater/M\&K; 2 edição, 2020.

KOELLREUTTER, Hans-Joachim. A Música da Índia. Rio de Janeiro: Embaixada da Índia. 1960.

KOELLREUTTER, Hans-Joachim e Satoshi TANAKA. Seiyó tono tai wa / DIALOG MIT DEM WESTEN. Versuch eines Beitrags zum Verstädnis einer fremden Kultur. Tóquio: Misei Universität, 1983.

KOELLREUTTER, Hans-Joachim. Introdução à estética e à composiçáo musical contemporânea. Organizado por Bernadete Zogonel e Salete M. La Chiamulera. Porto Alegre: Movimento, 1987.

KOELLREUTTER, Hans-Joachim. Música Ocidental \& Indiana: expressóes de diferentes níveis de consciência. Texto inédito. Rio de Janeiro, 1989.

KOELLREUTTER, Hans-Joachim. "Neue Musik aus Südamerika”. Em Im Zenit der Moderne. Die Internationalen Ferienkurse für Neue Musik Darmstadt 19461966. Geschichte und Dokumentationen in vier Bänden . Vol. 3, Editado por Gianmario Borio e Hermann Danuser. Freiburg: Rombach, 1997, p. 171-177.

KOELLREUTTER, Hans-Joachim. "Estética": À Procura de um Mundo sem "Vis-a-Vis" (Reflexóes Estéticas em Torno das Artes Orientais e Ocidentais)". Traduzido por Saloméa Gandelman. São João Del Rei: Editora UFSJ | Fundação Koellreutter, 2018.

MENDES, João. 2002. "A respeito da produção composicional de H. J. Koellreutter". Em BRASILIANA. Revista Quadrimestral da Academia Brasileira de Música, Número 11/ Maio: 24-29. 
LANGE, Francisco Curt. "Eine neues Musikzentrum Lateinamerikas. Die internationalen Musikseminare in Salvador". Em MONATSSCHRIFT FÜR ALLE GEBIETE DES MUSIKLEBENS SCHRIFTLEITUNG . DR. GÜNTER HAUSSWALD. ZWÖLFTER JAHRGANG, 1958, p. 659-663. Artigo preservado no IMD Archiv.

MAUSER, Siegfried. Emigranten bei den Internationalen Ferienkursen für Neue Musik in Darmstadt (1946-1951). Em Musik in der Emigration 1933-1945: Verfolgung Vertreibung - Rückwirkung. Editado por Horst Weber, 241-248. Stuttgart: J.B. Metzler, 1994, p. 241-248.

NOGUEIRA, Ilza. 2011. A criação musical em diálogo com o contexto político-cultural: o caso do Grupo de Compositores da Bahia, em Revista Brasileira de Música. v.24, n.2. Rio de Janeiro: Programa de Pós-graduação em Música - UFRJ, 2011, p. 351-380

NOGUEIRA, Lenita W. M.; ROSA, Lilia de Oliveira. Os Seminários de Música da Pro-Arte em São Paulo, em Anais do II Simpósio Internacional de Musicologia da UFRJ TEORIA, CRÍTICA E MÚSICA NA ATUALIDADE, 2011, p. 145-156.

NOGUEIRA , Ilza Maria Costa. Ernst Widmer - Perfil Estilístico. Salvador: UFBA, 1997.

NOGUEIRA, Ilza. Grupo de compositores da Bahia: Implicaçóes culturais e educacionais, em: Brasiliana, Revista da ABM No 1, ano 1, Jan. Rio de Janeiro: ABM, 1999, p. 28-35.

NOGUEIRA, Kenzo. Uma breve história da Escola de Música da UFBA. 2012.

NONNENMANN, Rainer. Mit Nachdruck: Texte der Darmstädter Ferienkurse für Neue Musik. Mainz: Schott Music GmbH \& Co. KG - Zeitschriften, 2010.

OLIVEIRA, Paula. Grupo de compositores da Bahia (1966-1974): desenvolvimento e identidade. Salvador: Master Diss., Universidade Federal de Salvador na Bahia, 2010.

PARASKEVAÍDIS, Graciela e KOELLREUTTER, Hans-Joachim. Zwei Gespräche mit Hans-Joachim Koellreutter. Hessischer Funk, Novembro, 1984.

PIMENTA, Pimenta, Emanuel Dimas de Melo. Koellreutter: as revoluçóes musicais de um mestre Zen. Plataforma Editora Independente CreateSpace, 2010.

REESE, Kirsten. Der hörende Blick ins Archiv. Reflexionen über Materialien aus dem Archiv des Internationalen Musikinstitut Darmstadt und andere Quellen, Em: Gender und Neue Musik: Von den 1950er Jahren bis in die Gegenwart. Editado por Vera Grund e Nina Noeske. Bielefeld: transcript Verlag, 2021, p. 43-67.

RISÉRIO, Antonio. Avantgarde na Bahia. Instituto Lina Bo e P.M. Bardi, 1995.

SCHLÜTER, Wilhelm. Vier Jahrzehnte Darmstadt. Em Musik \& Ästhetik. Heft 39. Julho Editado por Claus-Steffen Mahnkopf e Ludwig Holtmeier, 2006, p. 33-50.

SCHMIDT, Dörte. „Remigranten und musikalische Vergangenheitspolitik“. Zum Verhältnis von individuellem Handeln und institutionellem Rahmen bei der Rückkehr von Musik und Musikern“. Em Zwischen individueller Biographie und Institution. 
Zu den Bedingungen beruflicher Rückkehr von Musiker aus dem Exil. Editado por Matthias Pasdzierny e Dörte Schmidt. Schliengen: Ed. Argus, 2013, p. 30-64.

STEPHAN, Rudolph (ed.). Von Kranichstein zur Gegenwart: 50 Jahre Darmstädter Ferienkurse; 1946 - 1996. Internationale Ferienkurse für Neue Musik. Stuttgart: DACO-Verlag, 1996.

TRUDU, Antonio. La "scuola" di Darmstadt: I Ferienkurse dal 1946 a oggi. Milão: Unicopli, 1992.

TUMAT, Antje. Die Anfänge der Internationalen Ferienkurse für Neue Musik aus GenderPerspektive. Em: Gender und Neue Musik: Von den 1950er Jahren bis in die Gegenwart. Editado por Vera Grund e Nina Noeske. Bielefeld: transcript Verlag, 2021, p. 17-42.

WOLFF, Marcus Straubel. Ponte entre dois mundos: o oriente e o ocidente no pensamento estético de Koellreutter". XXVI Congresso da Associaçáo Nacional de Pesquisa e Pós-Graduação em Música - B. Horizonte, 2016. 